\title{
ANALISIS USAHATANI JAGUNG MANIS (Zea mays) DI DESA DALUNG KECAMATAN KUTA UTARA KABUPATEN BADUNG
}

\author{
Ir. A. A. Gde Pushpha, M.Si. \\ Program Studi Agribisnis, Fakultas Pertanian, Universitas Dwijendra \\ E-mail : agungpushpha@gmail.com \\ I Komang Pande Ariana, S.P \\ Program Studi Agribisnis, Fakultas pertanian, Universitas Dwijendara \\ E-mail : arikomang67@gmail.com
}

\begin{abstract}
Abstrak
Salah satu komoditas yang diusahakan oleh petani sejak lima tahun terakhir di Desa Dalung Kecamatan Kuta Utara Kabupaten Badung dalam upaya mewujudkan ketahan pangan seperti tertuang dalam renstra pembangunan pertanian adalah penanaman tanaman jagung manis. Judul penelitian analisis usahatani jagung manis di Desa Dalung,Kecamatan Kuta utara, Kabupaten Badung Tujuan usahatani jagung manis pada satu musim tanam ini adalah untuk mengetahui : (i) besarnya penggunaan biaya usahatani pada satu musim tanam; (ii) besarnya penerimaan dan pendapatan usahatani jagung manis pada satu musim tanam dan (iii) besar nys $\mathrm{R} / \mathrm{C}$ ratio pada usahatani jagung manis pada satu musim tanamJumlah populasi dalam penelitian 62 orang, jumlah sampel yang di ambil 30 orang dengan metode simple random sampling (acak sederhana), jenis data kuantitatif dan kualitatif, sumber data, data primer dan sekunder dan analisis data adalah anlisis usahatani dan kualitatif.Hasil penelitian menunjuk kan bahwa rata-rata biaya total yang dikeluarkan untuk usahatani jagung manis adalah 2.370.419.00/luas garapan, berdasarkan pada perhitungan Analisa usahatani rata-rata penerimaan dari usahatani jagung manis adalah sebesar 3.600.000.00 dan pendapatan dari usahatani jagung manis adalah sebesar Rp. 1.229.581.00/luas garapan.Di peroleh juga ratio penerimaan dan biaya usahatani nya $(\mathrm{R} / \mathrm{C})$,yaitu sebesar 1.5 ,karena $\mathrm{R} / \mathrm{C}$ ratio nya lebih besar dari pada 1 yaitu 1.5 maka usahatani jagung manis menguntungkan yang artinya setiap penambahan satu satuan input akan menyebabkan penambahan atau dengan kata lain usahatani jagung manis di Desa Dalung Kecamatan Kuta Utara Kabupaten Badung menguntungkan.Dapat disaran kan beberapa hal yaitu (i) diperlukan adanya peningkatan penyuluhan bagi para petani yang mengusahakan tanaman jagung manis guna dapat ditingkat kan produktivitas nya (ii) diperlukan adanya penelitian lebih lanjut mengenai aspek ekonomis dari pengembangan tanaman jagung manis pada kasus yang lebih besar guna dapat memperoleh kesimpulan yang lebih luas.(iii) agar dapat mempertahankan usahatani jagung manis dan jika memungkinkan memperluas areal, karena usahatani jagung manis dapat memberikan keuntungan yang lumayan.
\end{abstract}

Kata kunci : Analisis, Usahatani, Jagung Manis

\begin{abstract}
Abstrak
One commodity that has been devoted by farmers since the last five years in Dalung Village, North Kuta District, Badung Regency in an effort to realize food security as stated in the agricultural development plan is planting sweet corn plants. Title of research analysis of sweet corn farming in Dalung village, north Kuta subdistrict, Badung District. The purpose of sweet corn farming in one growing season is to find out: (i) the amount of use of farming costs in one planting season; (ii) the basis for revenue and income of sweet corn farming in one growing season and (iii) a large $\mathrm{R} / \mathrm{C}$ ratio in sweet corn farming in one planting season.The results showed that the average total cost incurred for sweet corn farming was Rp. 2.370.419.00 / arable, based on the calculation of farm analysis. The average acceptance of sweet corn farming was 3.600.000.00 and income from sweet corn farming is 1.229.581.00/wide arable. The population in this study was 62 people, the number of samples taken was 30 people with the method of simple random sampling, types of quantitative data, qualitative data sources, primary and secondary data and farm and qualitative analysis.Also obtained the ratio of revenue and the cost of farming $(\mathrm{R} / \mathrm{C})$, which is equal to 1.5 , because the $(\mathrm{R} / \mathrm{C})$ ratio is greater than 1 , that is 1.5 , sweet corn farming is profitable, which means that every addition of one input unit will cause the addition or in words another sweet corn farming in Dalung Village, North Kuta District, Badung Regency is profitable.It can be suggested several things, namely (i) it is necessary to increase counseling for farmers who work on sweet corn to increase their productivity (ii) further research is needed on the economic aspects of developing sweet corn plants in larger cases to be able to obtain broader conclusions (iii) in order to maintain the sweet corn farming and if possible expand the area, because the sweet corn farming can provide a considerable profit.
\end{abstract}

Keyword : Analysis, of Sweet, Corn Farming 


\section{PENDAHULUAN}

Pembangunan pertanian di Indonesia sangat penting apa lagi untuk keseluruhan pembangunan ekonomi, dan semenjak sektor pertanian ini menjadi penyelamat perekonomian nasional karena justru pertumbuhan nya meningkat, sementara sektor lain pertumbuhan nya negatif. beberapa alasan yang mendasari penting nya pertanian di Indonesia : (1) potensi sumber daya yang besar dan beragam, (2) pendapatan nasional cukup besar, (3) rata-rata penduduk menggatungkan hidup nya pada sektor ini dan (4) menjadi basis pertumbuhan di pedesaan, potensi pertanian yang besar namun sebagian besar dari petani banyak yang yang masi tergolong miskin dan ini sangat ironis karena terjadi di Indonesia. hal ini menjelaskan bahwa pemerintah bukan saja kurang memberdayakan petani tetapi juga sektor pertanian keseluruhan.(2005) Malang, fakultas pertanian universitas brawijaya)

Pertanian di Indonesia merupakan salah satu penunjang kehidupan masyarakat Indonesia, oleh karena itu, sektor pertanian memerlukan pertumbuhan ekonomi yang kukuh dan pesat. Sektor pertanian ini juga perlu menjadi satu komponen utama dalam program dan strategi pemerintah untuk mengatasi kemiskinan, di masa lampau pertanian Indonesia telah mencapai hasil yang baik dan memberikan konstribusi penting dalam pertumbuhan ekonomi Indonesia. termasuk menciptakan lapangan pekerjaan dan penganguran menurun drastis (Anon,2003)

Lebih lanjut di sebutkan bahwa pada beberapa daerah telah terjadi penurunan produktivitas panen tanaman pangan, di tambah mayoritas petani yang bekerja di sawah memiliki lahan Kurang dari 0,5 ha sehingga pendapatan petani masih ralatif rendah. meskipun telah ada pertanian dengan nilai tambah yang tinggi, pengaruh diversifikasi tebatas hanya pada daerah dan komoditas tertentu di dalam setiap sub sektor. ini menjadi tantangan bagi pemerintah yang baru agar lebih keras lagi dalam peningkatan produktivitas dan penghasil di daerah rural, dan memberikan fondasi jangka Panjang dalam peningkatan produktivitas secara terus menerus untuk menjawab tantangan tersebut serta mewujudkan pertanian organik di perdesaan.. Tujuan pertanian organik di dunia secara garis besarnya adalah sama yaitu untuk melaksanakan kegiatan bertani yang ramah lingkungan, sehingga menghasilkan produk yang relatif sehat yang pada akhirnya dapat peningkatkan kesejahteraan petani, kesehatan konsumen dan kesehatan lingkungan (Dananjaya dan Yewa, 2018)

Hal ini menjadi sangat penting untuk 1. Fokus dalam pendapatan petani, titik berat pada padi tidak lagi dapat menjamin segi pendapatan petani maupun program keamanan pangan.2. Peningkatan produktivitas adalah kunci dalam peningkatan pendapatan petani oleh karena itu pembangunan ulang dan sistem tambahan menjadi sangat menentukan.3. Dana di perlukan, dan dapat diperoleh dari usaha sementara untuk memenuhi kebutuhan kredit para petani melalui skema kredit yang di biayai oleh APBN.4. Pertanian yang telah memiliki sistem irigasi sangat penting dan di pandang sebagai aktivitas antar sektor, pemerintah perlu memperhatikan intergritas infastruktur dengan keterlibatan pengguna irigasi secara lebih intensif, dan meningkat kan efisiensi penggunaan air untuk mencapai panen yang lebih optimal hingga setiap tetes air.5. fokus dari peran regulasi dari depertemen pertanian perlu di tata ulang kualitas input yang rendah yang mempengaruhi produktifitas petani, karantina juga di perlukan untuk melindungi kepentingan petani dari penyakit luar namun pada saat yang bersamaan juga tidak membatasi masuk nya bahan impor, dan standar produk secara terus menerus di tingkatkan di dalam pembelian swasta bukan oleh pemerintah. 
Pemerintah dimasa mendatang diharapkan mampu menumbuhkan sektor pertanian, sehingga pada giliran nya mampu menjadi sumber pertumbuhan baru bagi perekonomian Indonesia khusunya dalam hal pencapaian sasaran : (1) mensejahterakan petani, (2) menyediakan pangan, (3) sebagai wahan pemerataan pembangunan untuk mengatasi kesanjangan pendapatan masyarakat maupun antar wilayah, (4) merupakan pasar input pengembangan agroindustry, (5) menghasilkan devisa, (6) menyediakan lapangan pekerjaan, (7) peningkatan pendapatan nasional dan (8) tetap mempetahan kan kelestarian sumberdaya (Anon,2005)Dalam upaya menyediakan pangan, komoditas jagung merupakan tanaman yang penting setelah tanaman padi. Saat ini pemerintah telah mencanangkan pengembangan tanaman jagung yang di tunjukkan untuk memenuhi kebutuhan pangan selain peningkatan pandapatan petani, seperti yang telah di kembangkan secara meluas di provinsi Gorontalo.Salah satu hasil penelitian yang dilakukan didesa gondanglegi, malang, jawa timur menunjukkan bahwa budidaya jagung manis menjadi harapan baru petani dengan biaya murah dan dalam waktu singkat modal kembali Bersama keuntungan yang lumayan. Pranowo (2007) mengatakan bahwa keuntungan petani jagung manis di desa pandanrejo sebesar Rp. 9.345.280.00/ha.untuk perhitungan efisiensi dan kelayakan usahatani jagung manis di Desa Pandanrejo dapat dikatakan efisiensi dan layak di kembangkan.

Salah satu Kabupaten di Provinsi Bali, yaitu Kabupaten Badung masih memiliki lahan sawah yang relatif luas dan di sisi lain pembangunan di luar sektor pertanian juga semakin kuat. Keadaan yang seperti ini dapat mengancam kelestarian lingkungan khusus nya sawah termasuk juga alih profesi, apabila penghasilan dari sawah nya dianggap tidak dapat mencukupi kebutuhan hidup keluarga petani. Salah satu langkah strategis yang telah di ambil oleh pemerintah kabupaten badung adalah dengan menetap kan rencana strategi (renstra) dinas pertanian kabupaten badung. Pada renstra tersebut di nyatakan bahwa visi pembangunan pertanian adalah terwujudnya pertanian yang Tangguh modern dan efisien menuju ketahanan pangan yang berbasis agribisnis untuk kesejahteraan masyarakat petani.Salah satu komoditas yang diusahakan oleh petani sejak lima tahun terakhir di Desa Dalung, Kecamatan Kuta Utara, Kabupaten Badung dalam upaya mewujudkan ketahan pangan seperti tertuang dalam renstra pembangunan pertanian adalah Penanaman jagung manis, namun dalam pengembangan usahatani jagung manis seringkali di temukan permaslahan yaitu rendah nya produktifitas usahatani karena keterbatasan lahan, kurangnya modal untuk pembelian sarana produksi terutama untuk pembelian benih, pupuk dan obat-obatan yang harganya semakin lama semakin tinggi, di sisi lain harga jagung manis mengalami fliktuasi sehingga meskipun secara nominal harga jagung manis tinggi akan tetapi biaya yang di keluarkan petani juga tinggi. sehingga petani dalam berusaha tani harus memperhitungkan biaya yang di keluarkan, penerimaan yang mereka terima, keuntungan yang di peroleh dan efisiensi dari usaha tani nya (Noviana,2003), oleh karena itu, guna mengantisipasi pengembangan tanaman jagung manis dari aspek ekonomis nya, di perlukan adanya penelitian kearah tersebut, yang menganalisis usahatani tanaman jagung manis.

Dari uraian latar belakang yang telah di sebutkan di atas di rumuskan beberapa permasalahannya, sebagai berikut 1. Berapakah besar penggunaan biaya untuk usahatani jagung manis pada satu musim tanam di Desa Dalung, Kecamatan Kuta utara, Kabupaten Badung? 2. Berapakah besar penerimaan dan pendapatan petani dari usahatani jagung manis pada satu musim tanam di Desa Dalung, Kecamatan Kuta Utara, Kabupaten Badung ? 3. Berapakah RC rasio dalam usahatani jagung manis yang di usahakan oleh 
petani dalam satu musim tanam di Desa Dalung,kecamatan Kuta Utara,Kabupaten Badung?1. Untuk mengetahui besarnya penggunaan biaya untuk usaha tani jagung manis pada satu musim tanam di Desa Dalung Kecamatan Kuta Utara Kabupaten Badung:2. Untuk mengetahui besar penerimaan dan pendapatan petani dari usaha tani jagung manis pada satu musim tanam di Desa Dalung Kecamatan Kuta Utara Kabupaten Badung: 3. Untuk mengetahui besar nya R/C rasio dalam usaha tani jagung manis dalam satu musim tanam di Desa Dalung Kecamatan Kuta Utara Kabupaten Badung

\section{METODE}

Penelitian ini dilakukan di Desa Dalung, Kecamatan Kuta Utara, Kabupaten Badung. Pemilihan lokasi ini di tentukan dengan Teknik simple random sampling, dengan pertimbangan yaitu sebagai berikut : 1.Petani di Desa Dalung, Kecamatan Kuta Utara, telah mengembangkan jagung manis pada lahan sawah nya setelah tanaman padi di panen. 2. Petani di wilayah ini belum memahami aspek ekonomis secara menyeluruh yang di peroleh dari usahatani jagung manis. Populasi dalam penilitian ini adalah seluruh petani yang mengembangkan usahatani jagung manis di Desa Dalung, Kecamatan Kuta Utara, Kabupaten Badung, yaitu sebanyak 62 petani, pada penelitian ini tidak semua petani di ambil untuk di jadikan unit penelitian karena adanya keterbatasan dana,waktu dan tenaga.jadi menggunakan Teknik simple random sampling (acak sederhana), yaitu jumlah sampel yang diambil sebanyak 30 orang petani.

Data yang di perlukan dalam penelitian ini adalah data primer dan data sekunder baik yang bersifat kualitatif ataupun kuantitatif yang berkenan dengan aspek ekonomis pengembangan usahatani jagung manis. Berikut Teknik pengumpulan data baik yang berupa data primer dan data sekunder yang di gunakan dalam penelitian ini adalah sebagai berikut :1.Daftar pertanyaan (kuesioner)Kuesioner atau daftar pertanyaan di persiapkan untuk di ajukan kepada sampel dengan tujuan dapat memperoleh informasi yang relavan.Yaitu data karakterristik petani termasuk juga dengan aspek ekonomis, seperti besarnya biaya usahatani, produksi dan harga jagung manis di tingkat petani.2. Wawancara ini ialah salah satu Teknik untuk mendapat kan data yang digunakan agar mendapat informasi dengan cara bertanya langsung kepada sampel, yaitu untuk mendapat kan informasi yang lebih jelas pada kuesioner yang telah di siap kan.3. Pengamatan atau observasi, Pengamatan yang dilakukan secara langsung di objek penelitian untuk dapat memperoleh gambaran yang lebih jelas dan dapat mengetahui keadaan yang sebenarnya, serta melengkapi informasi yang sudah di peroleh pada saat wawancara.4. Dokumentasi Teknik ini adalah cara pengumpulan data dengan menggunakan sebagian data yang ada dari penelitian sebelum nya, yang bersumber dari dinas pertanian dan lain sebagainya.

Data primer di peroleh dari metode survei yaitu data yang didapatkan dari hasil Wawancara terhadap petani sampel yang telah didapatkan dari hasil kuesioner sebagai alat pengumpul data yang pokok ( singarimbun dan effendi, 1989) daftar pertanyaan pada kuesioner meliputi : umur petani, lama pedidikan formal, penggunaan sarana produksi, produksi, tingkat harga dan lain sebagainya. Sedngkan data sekunder yang di perlukan sebagai data penunjang dapat di peroleh dari kantor kepala desa dan kantor camat serta dokumentasi lain nya yang di kantor pemerintah (Teknik dokumentasi). Maupun non pemerintah termasuk di perguruan tinggi/universitas dan sumber lain nya. Metode yang digunakan adalah analisis secara deskriptif dan analisis usahatani. Data yang sudah terkumpul selanjut nya akan di masukkan kedalam tabel- 
tabel tetentu yang sesuai dengan tujuan penelitian itu untuk dapat memudah kan kebutuhan analisis. Analisis secara deskriptif merupakan metode yang menggambarkan segala fenomena tertentu yang berkenan dengan penelitian ini yang sekaligus memberikan interpretasi kepada data yang telah dikumpulkan dan hasil analisis kuantitatif. Analisis kuantitatif adalah analisis usaha tani yang bersumber dari kegiatan usahatani melon dalam satu periode produksinya . untuk mengetahui biaya usahatani, penerimaan usahatani dan pendapatan bersih usahatani dapat di hitung dengan menggunakan rumus ( soekartawi, 1995), sebagai berikut :1. Penerimaan Rumus : TR $=\mathrm{Y}$ x PyKeteranagan :TR: total penerimaanY : produksi yang di peroleh dalam satuusahataniPy :harga y 2. Biaya Rumus : $\mathrm{TC}=\mathrm{FC}+\mathrm{VC}$ Keterangan $: \mathrm{TC}=$ total biaya $($ total cost $) \mathrm{FC}=$ biaya tetap $($ fixed cost $) \mathrm{VC}=$ biaya tidak tetap (variable cost) 3. PendapatanRumus $: \mathrm{PD}=\mathrm{TR}-\mathrm{TCKeteranagan}: \mathrm{PD}=$ pendapatan petaniTR $=$ penerimaan total (total revenue) $\mathrm{TC}=$ biaya total (total cost) Sedangkan untuk dapat mengetahui tingkat kelayakan tehadap usahatani jagung manis ini di gunakan analisis $\mathrm{R} / \mathrm{C}$ ratio. Makin besar nilai ratio maka usahatani itu semakin menguntungkan untuk diusahakan. Perhitungan R/C ratio menggunakan formulasi :R/C RasioRumus : $\mathrm{a}=$ TR/TCKeterangan :A : RasioTR : penerimaan total (total revenue) TC : biaya total (total cost)

\section{HASIL DAN PEMBAHASAN}

Secara geografis Desa Dalung,Kecamatan Kuta Utara,Kabupaten Badung memiliki batas-batas wilayah seperti di bawah ini :1.Sebelah utara Desa Abianbase2.Sebelah Timur Kelurahan Sempidi dan Desa Padangluih3.Sebelah Selatan Desa Kelurahan Kerobokan Kaja dan Desa Tibubeneng 4.Sebelah Barat Desa Buduk dan Desa Sebagian Canggu Jarak antara lokasi penelitian Desa Dalung dengan pusat pemerintahan adalah $3 \mathrm{~km}$, awal nya wilayah yang sudah menjadi Desa dalung sekarang ini merupakan Sebagian semaksemak dan tegalan, dan juga terdiri dari tanah persawahan yang subur.Sebelah timurnya adalah sebuah wilayah Desa yang disebut dengan Padangluah atau yang sekarang dikenal dengan nama Padangluih, jaraknya hanya dibatasi dengan sungai yang dikenal dengan nama sungai Yeh poh yang mengalir ke laut selatan bali.

Luas lahan sawah Desa Dalung,kecamatan Kuta utara,Kabupaten Badung adalah 92,25 ha, seperti hal nya dengan daerah lain di bali,wilayah dalung ini mempunyai dua musim, musim kemarau dan musim hujan.Sarana dan prasarana transportasi yang menuju desa dalung sangat baik,karena terhubung atau dilintasi jalan aspal yang sekaligus jalan pedesaan, dengan demikian Desa Dalung Kecamatan Kuta Utara Kabupaten Badung dapat dengan mudah dijangkau menggunakan roda dua maupun roda empat. Desa Dalung memiliki luas wilayah 675,71 hektar, yang penggunaan lahannya terdiri atas sawah 92,25 ha,pekarangan 41.06 ha,perkebunan 188,2 ha,kuburan 1,23 ha,pemukiman 256 ha dan lain-lain 30,75 ha.Beberapa jenis hasil produksi yang dihasilkan di Desa Dalung,Kecamatan Kuta Utara,Kabupaten Badung seperti pada sektor pertanian diantara nya padi sawah, kacang Panjang, cabe, terong,buncis dan jagung manis.

Lahan merupakan salah satu faktor produksi yang sangat penting, hal ini erat kaitannya dengan mata pencaharian petani yang semuanya sebagai petani atau bekerja pada sektor pertanian. Luas kepemilikan dan penguasaan lahan juga akan mempengaruhi tingkat pendapatan, artinya semakin luas lahan yang dimiliki dan di garap maka hasil yang diperoleh dari usahatani akan semakin tinggi, sehingga pendapatan 
petani juga akan semakin meningkat. luas kepemilikan lahan adalah luas yang dimiliki petani baik yang digarap maupun yang tidak digarap, sedangkan luas penguasaan lahan adalah luas lahan yang digarap oleh petani.Dari 30 petani sampel seluruh nya merupakan petani pemilik lahan dengan luas garapan rata-rata 86 are. Sedangkan usahatani jagung manis dikelola pada lahan garapan rata-rata 20 are, yang diusahakan untuk usahatani jagung manis, selebihnya ditanami sayuran tanaman lain seperti terong, kacang panjang dan buncis.Kebanyakan penduduk Desa Dalung, Kecamatan Kuta utara, Kabupaten Badung bekerja lebih dari satu jenis pekerjaan, hal ini disebabkan hasil dari pekerjaan utama dirasa belum cukup untuk memenuhi kebutuhan rumah tangganya. Berdasarkan hasil penelitian terhadap 30 petani sampel, seluruhnya (100\%) memiliki pekerjaan pokok sebagai petani dan seluruhnya memiliki pekerjaan sampingan sebagai peternak, seperti sapi, babi dan ayam.

Tujuan utaman dalam kegiatan usahatani adalah untuk mencapai produksi dibidang pertanian yang pada akhirnya produksi itu akan di nilai dari jumlah penerimaan yang diperoleh dengan biaya yang telah dikeluarkan dalam proses produksi tersebut (soekartawi , 1987 ).Dari hasil penelitian didapat kan bahwa luas usahatani jagung manis pada petani jagung manis berkisar antara 10 sampai 30 are dengan rata-rata seluas 20 are. Dari rata-rata luas garapan usahatani jagung manis didapat produksi sebesar $1.200 \mathrm{~kg} / \mathrm{luas}$ garapan atau $6.000 \mathrm{~kg} / \mathrm{ha}$

Biaya usahatani dalam penelitian ini diklasifikasikan ke dalam biaya tetap dan tidak tetap. Yang tergolong biaya tidak tetap mencakup sarana produksi (benih, pupuk, obat-obatan dan tenaga kerja), sedangkan yang termasuk biaya tetap seperti alat-alat pertanian dan lain-lain. Biaya sarana produksi adalah biaya yang dikeluarkan oleh petani sampel dalam proses produksi. Besarnya biaya produksi dipengaruhi oleh beberapa faktor antara lain struktur tanah, tofografi tanah, jenis dan varieties tanaman serta teknologi yang digunakan. Biaya rill yang dikeluarkan oleh petani sampel dalam usahatani jagung manis sebesar Rp. 2.370.419.00/luas garapan

Biaya tenaga kerja diperoleh dengan mengalikan total curahan tenaga kerja HOK/luas garapan dengan upah yang berlaku saat itu. Biaya total yang dikeluarkan untuk curahan tenaga kerja pada usahatani jagung manis rata-rata sebesar Rp. 2.000.000/luas garapan yang menggunakan tenaga kerja luar rumah tangga dan tenaga kerja dalam rumah tangga.

Alat pertanian yang termasuk dalam biaya tetap sangat dibutuhkan dalam mengusahakan uasahatani jagung manis seperti cangkul, sabit, sekop dan spreyer (alat semprot) yang harganya sebesar Rp. 380.000.00. Penggunaan alat-alat pertanian dalam usahatani jagung manis di Desa Dalung, Kecamatan Kuta utara, Kabupaten Badung tercantum sebagai berikut :a. Cangkul,cangkul yang digunakan dalam usahatani jangung manis yaitu untuk mengilah lahan sebelum ditami agar tanah menjadi gembur. Cangkul yang dimiliki oleh masing-masing petani rata-rata satu unit dengan harga Rp. 50.000.00/buah. Cangkul dapat digunakan kurang lebih selama lima tahun.b. Sabit,sabit sebagai alat untuk membersihkan rerumputan atau gulma yang tumbuh pada lahan yang akan ditanami jagung manis. Sabit dapat digunakan kurang lebih selam lima tahun yang rata-rata dimiliki oleh petani sebanyak satu buah dan harganya sebesar Rp. 20.000.00/buah.c. Sekop,sekop dapat digunakan untuk membuat gundukan tanah dan selokan yang akan ditanami. Sekop dimiliki oleh setiap petani masing-masing satu unit dan dapat digunakan selama lima tahun dengan harga Rp. 60.000.00/buah.d. Spreyer (alat semprot),Spreyer merupakan alat untuk 
menyemmprot hama dan penyakit tanaman jagung manis, alat ini dimiliki setiiap petani masing-masing satu unit dengan Sedangkan biaya penyusutan alat-alat pertanian yang digunakan untuk usahatani jagung manis dihitung dengan metode garis lurus ( straight line method) (hermanto, 1993) dengan rumus sebagai berikut $: X=\underline{\mathrm{Nb}}-\mathrm{Nsketeranagan} \mathrm{X}$ : Besarnya penyusutan $(\mathrm{Rp} / \mathrm{tahun}) \mathrm{Ns}$ : nilai sisa $=0(\mathrm{Rp}) \mathrm{Nb}$ : nilai pembelian $n$ : umur ekonomisbesar nya alat penyusutan pertanian pada usahatani jagung manis sebagai berikut :Cangkul $: \underline{X=N b-N s / n} \underline{X=N b-N s / n} X=R p . \underline{50.000 .0 / 5}=R p .10 .000 .00 /$ tahun Sabit $: \underline{X=N b-N_{s}} / n$

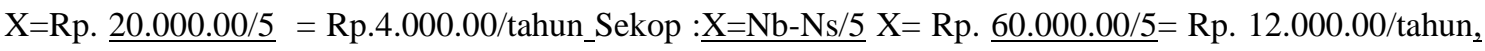
Sprayer $: \underline{X=N b-N s / 5} X=R p . \underline{250.000 .00 / 10}=$ Rp. 25.000,00/tahun

Metode ini digunakan dengan asumsi bahwa alat-alat pertanian yang digunakan dalam usahatani jagung manis menyusut dalam besaran yang sama dalam setiap tahun. Selanjutnya, biaya usahatani jagung manis dalam semusim termasuk biaya penyusutan alat-alat pertanian yang digunakan dalam usahatani tersebut dapat dilihat pada tabel 1_Pendapatan merupakan selisih antara penerimaan dengan biaya usahatani. menurut soekartawi (1987) penerimaan adalah jumlah produksi dari komoditas yang dihasilkan oleh petani dikalilan dengan harga yang berlaku pada saat itu. Penerimaan petani dari usahatani jagung manis pada Desa Dalung,Kecamatan Kuta utara,Kabupaten Badung juga dihitung berdasar konsep tersebut :

Tabel 1 Rata-rata biaya usahatani jagung manis di Desa Dalung,Kecamatan Kuta utara, Kabupaten Badung untuk satu ha (100 are)

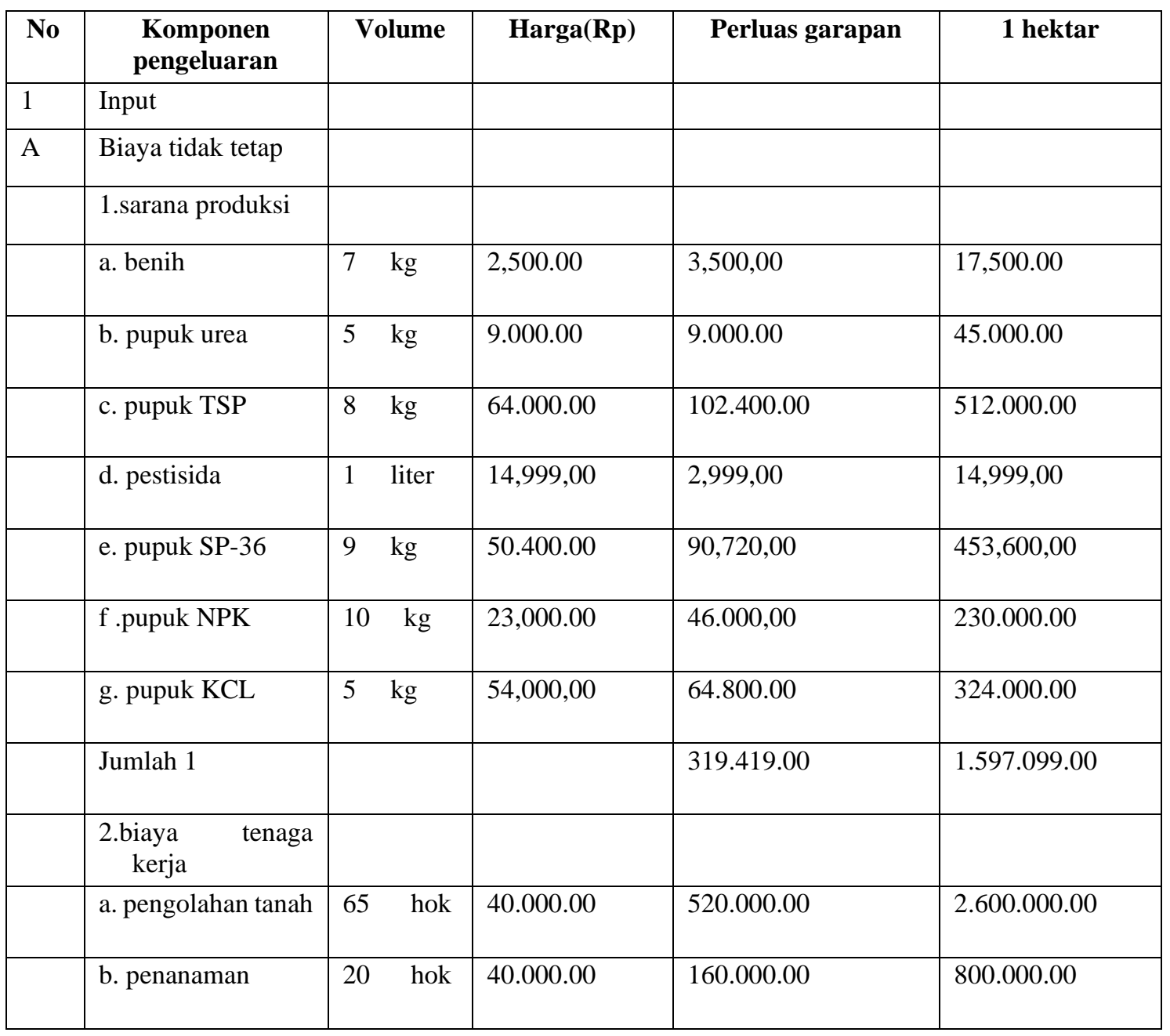


dwijenAGRO Vol. 10 No. 2, November 2020 ISSN : 1979-3901

\begin{tabular}{|c|c|c|c|c|c|}
\hline & c. pemupukan & 15 hok & 40.000 .00 & 120.000 .00 & 600.000 .00 \\
\hline & d. berantas hama & 20 hok & 40.000 .00 & 160.000 .00 & 800.000 .00 \\
\hline & e. panen anggkut & 75 hok & 40.000 .00 & 600.000 .00 & 3.000 .000 .00 \\
\hline & f. pengairan & 20 hok & 40.000 .00 & 160.000 .00 & $800.000 ; 00$ \\
\hline & g. pengawasan & 15 hok & 40.000 .00 & 120.000 .00 & 600.000 .00 \\
\hline & h. penyemprotan & 20 hok & 40.000 .00 & 160.000 .00 & 800.000 .00 \\
\hline & Jumlah 2 & & & 2.000 .000 .00 & 10.000 .000 .00 \\
\hline & Jumlah A & & & 2.319 .419 .00 & $11,597.099 .00$ \\
\hline B & 1. Biaya tetap & & & & \\
\hline & a. cangkul & 1 buah & 50.000 .00 & 10.000 .00 & 10.000 .00 \\
\hline & b. sabit & 1 buah & 20.000 .00 & 4.000 .00 & 4.000 .00 \\
\hline & c. sekop & 1 buah & 60.000 .00 & 12.000 .00 & 12.000 .00 \\
\hline & d. sprayer & 1 buah & 250.000 .00 & 25.000 .00 & 25.000 .00 \\
\hline & Jumlah B & & & 51.000 .00 & 51.000 .00 \\
\hline & Jumlah A+B & & & 2.370 .419 .00 & $11,648,099.00$ \\
\hline & Output & & & & \\
\hline & $\begin{array}{l}\text { 1.total produksi } 5 \\
\text { ton }\end{array}$ & $6.000 \mathrm{~kg}$ & & & \\
\hline & $\begin{array}{l}\text { 2.harga per } \mathrm{kg} \text { di } \\
\text { tingkat petani }\end{array}$ & & 3.000 & & \\
\hline & $\begin{array}{ll}\text { 3.nilai } & \text { total } \\
\text { produksi } & \end{array}$ & $1.200 \mathrm{~kg}$ & 3.000 & & 18.000 .000 .00 \\
\hline & 4. pendapatan & & & & 6.351 .901 .00 \\
\hline & 5. biaya pokok & & & & \\
\hline III & $\mathrm{R} / \mathrm{C}$ & & & & 1.5 \\
\hline
\end{tabular}

Sumber : Diolah Dari Data Primer

Data yang tertuang pada tabel 1 menunjukkan sebagai berikut : Rata-rata biaya usahatani jagung manis di perhitungkan sebesar Rp. 2.370.419.00/luas garapan, terinci menjadi biaya tidak tetap sebesar Rp.51.000.00, jika di cermati lebih lanjut biaya tidak tetap terdiri atas sarana produksi sebesar Rp. 2.319.419.00/luas garapan dan upah tenaga kerja sebesar Rp. 2.000.000.00/luas garapan dapat disajikan dengan rumus Rumus : $\mathrm{TC}=\mathrm{FC}+\mathrm{VC}$ Keterangan $: \mathrm{TC}=$ total biaya $($ total cost $) \mathrm{FC}=$ biaya tetap $($ fixed cost) 
$\mathrm{VC}=$ biaya tidak tetap (variable cos) Total biaya $($ total cost $)=$ Rp. 51.000.00 + Rp. 2.319.419.00 Total biaya $($ total cost $)=$ Rp. 2.370.419.00 Besarnya penerimaan yang diperoleh petani dari usahatani jagung manis di Desa Dalung, Kecamatan Kuta utara, Kabupaten Badung sebesar Rp. 3.600.000.00 data ini didapat dari harga rata-rata jagung manis di petani sebesar Rp.3.000.00/kg yang dikalikan dengan produksi jagung manis per luas garapan sebesar $1.200 \mathrm{~kg}$. cara penghitungan penerimaan usahatani jagung manis dengan menggunakan rumus :TR $=$ Q.Pq Keterangan $: \mathrm{TR}=$ total penerimaan (total revenue $) \mathrm{Q}=$ produksi yang diperoleh dalam suatu usahatani $\mathrm{Pq}=$ harga produk $\mathrm{Q}$ (price of $Q$ ) Total penerimaan : 1.200kg x Rp.3,000 Total penerimaan : Rp. 3.600.000.00 Dengan pengolahan lahan seluas 20 are maka diperoleh penerimaan keseluruhan dari hasil usahatani jagung manis dalam satu musim tanam sebesar Rp.3.600.000.00 pendapatan usahatani jagung manis adalah penerimaan dikurangi biaya-biaya rill yang dikeluarkan untuk usahatani jagung manis dalam satu musim tanam perluas garapan sebesar Rp. 2.370.419.00 untuk lebih rincinya dalam pengolahan data ini menggunakan rumus :Rumus $: P D=T R-T C$ Keterangan Pd = pendapatan petani $\mathrm{Tr}=$ penerimaan total ( total revenue $) \mathrm{Tc}=$ biaya total (total cost) Pendapatan petani $=\mathrm{Rp}$. 3.600.000.00- 2.370.419.00 Pendapatan petani = Rp. 1.229.581.00 Untuk mengetahui analisis kelayakan usahatani jagung manis di Desa Dalung, Kecamtan Kuta utara, Kabupaten Badung perluas garapan dengan menggunakan rumus : R/C adalah singkatan dari return cost ratio. Analisis R/C ratio digunakan untuk membandingkan antara penerimaan dan biaya produksi ( soekartawi 1995). $\mathrm{Rumus}: \mathrm{a}=\mathrm{R} / \mathrm{Ca}=$ $\{($ py.y $) /(\mathrm{FC}+\mathrm{VC})\}$ input data :total penerimaan : Rp. 3.600.000.00total biaya produksi : Rp.2.370.419.00 $\mathrm{R} / \mathrm{C}=\{(\mathrm{Rp} .3000 \times 1.200 \mathrm{~kg}) /(\mathrm{Rp} .2 .319 .419 .00+\mathrm{RP} .51 .000 .00)\} \mathrm{R} / \mathrm{C}=\{\mathrm{Rp} .3 .600 .000 .00 / \mathrm{Rp}$. 2.370.419.00 $\mathrm{R} / \mathrm{C}=1.5$ Untuk mengetahui analisis perluas garapan uasahatani jagung manis dapat dilihat pada tabel 2

Tabel 2. Rata-rata pendapatan kotor, jumlah biaya dan pendapatan bersih usahatani jagung manis/luas garapan di Desa Dalung, Kecamatan Kuta utara, Kabupaten Badung

\begin{tabular}{|c|c|c|}
\hline $\begin{array}{c}\text { Pendapatan kotor } \\
(\mathbf{R p})\end{array}$ & $\begin{array}{c}\text { Jumlah biaya } \\
(\mathbf{R p})\end{array}$ & $\begin{array}{c}\text { Pendapatan bersih } \\
(\mathbf{R p})\end{array}$ \\
\hline 3.600 .000 .00 & 2.370 .419 .00 & 1.229 .581 .00 \\
\hline
\end{tabular}

Sumber : Diolah dari Data Primer

Dari tabel 2 di atas menunjuk kan bahwa pendapatan kotor petani sampel sebesar Rp. 3.600.000.00, biaya yang dikeluarkan dalam usahatani jagung manis sebesar Rp. 2.370.419.00 dan pendapatan bersih petani sampel sebesar Rp. 1.229.581.00 perluas garapan (20 are ). Untuk mengetahui pendapatan usahatani jagung manis perluas garapan adalah dengan memakai rumus :Pd $=$ TR-TC Pd $=$ Rp. 3.600.000.002.370.419.00 Pd = Rp. 1.229.581.00 Dan kelayakan usahatani jagung manis di Desa Dalung, Kecamatan Kuta Utara, Kabupaten Badung dalam luas garapan (20 are ) adalah sebagai berikut $:$ Rumus : R/C Ratio = $\mathrm{TR} / \mathrm{TC}=\underline{\mathrm{Rp} .3 .600 .000 .00 / R p}$. 2.370.419.00 = 1.5 Karena R/C ratio nya lebih besar daripada 1 yaitu 1.5 maka usahatani jagung manis menguntungkan yang artinya setiap penambahan satu satuan input akan menyebabkan penambahan.

\section{PENUTUP}

\section{Simpulan}


Berdasarkan pada hasil penelitian dan pembahasan yang telah diuraikan diatas dapat ditarik beberapa kesimpulan sebagai berikut :1.Rata-rata biaya yang dikeluarkan untuk usahatani jagung manis oleh petani sampel adalah sebesar Rp. 2.370.419.00/luas garapan 2. Rata-rata jumlah pendapatan adalah Rp. 1.229.581.00/luas garapan dan rata-rata penerimaan petani usahatani jagung manis adalah Rp. 3.600.000.00/luas garapan 3. besarnya $\mathrm{R} / \mathrm{C}$ ratio 1.5 berarti usahatani jagung manis menguntungkan

\section{Saran}

Memperhatikan kesimpulan yang telah disebutkan di atas, dapat disarankan beberapa hal sebagai berikut. (1)diperlukan adanya peningkatan penyuluhan bagi para petani yang mengusahakan tanaman jagung manis guna dapat ditingkat kan produktivitasnya.(2).diperlukan adanya penelitian lebih lanjut mengenai aspek ekonomis dari pengembangan tanaman jagung manis pada kasus yang lebih besar guna dapat memperoleh kesimpulan yang lebih luas.(3).agar dapat mempertahankan usahatani jagung manis dan jika memungkinkan memperluas areal, karena usahatani jagung manis dapat memberikan keuntungan yang lumayan.

\section{DAFTAR PUSTAKA}

Anderson. (1979). petunjuk modern kepada kesehatan". Indonesia Publ. House.

Anonimus . (2009)."Jagung Manis Agar Tetap Manis". http://www.tanindo.com/abdi4/hal2301.htm.

Anonimus. (2003). "Indonesia Expanding Horizon". Jakarta.

Anonimus. (2005). "Pertanian dan Pembangunan Pertanian di Indonesia". Malang: Fakultas Pertanian Universitas Brawijaya.

Anonimus. (2007). "Usaha Tani Jagung Manis". Jakarta Agrojurnal Pertanian, 29 november 2007.

Dananjaya, I.G.A.N dan P. Yewa. 2018. Perbandingan Pendapatan Petani Sebelum dan Sesudah Mengikuti Program Gerbang Pangan Serasi di Subak Empas Kubontingguh, Desa Denbantas, Kecamatan Tabanan, Kabupaten Tabanan. Jurnal dwijenAGRO, Vol. 8. No.1.

Hermanto, F. (1986). Pengantar Ekonomi pertanian. Jakarta:LP3ES.

Hermanto, F. (1989). "Ilmu Usahan Tani". Jakarta:swadaya.

Irdiana, i.y. sugito dan A . sugianto. 2002 pengaruh dosis pupuk organik cair dan dosis pupuk urea terhadap pertumbuhan hasil tanaman jagung manis (Zea mays saccharata sturt) varietas bisi sweet.agrivita 24 (1)

Kadarsan. 2011.usahatani.http://punya kadarsan.blogspot.com/2012/06/apa itu usahatani.html,di akses pada tanggal 10 mei 2016.

Karyati, Ni Ketut. (2008). "Pengaruh Dosis Nitrogen dan Populasi terhadap Hasil Kadar Protein Kasar Brangkasan Jagung Manis (zea mays saccharata sturt)" Tesis untuk Memperoleh Gelar Magister pada Program Magister. Program studi Pertanian Lahan Kering, Program Pascasarjana Universitas Udayana, Denpasar.

Noviana S, Endang. (2003). Analisa Efisiansi Usaha Tani Jagung Manis (zea mays Saccharata Sturt)(Studi Kasus Didesa Pandanrejo Kecamatan Bumiaji Kota Batu),. Univ. Muhamadiah, Malang.

Pranowo, Tri. (2007). "Laris Manis Bisnis Sweet corn". Jakarta Selatan:"Tabloid Agribisnis Dwimingguan Agrina, 19/04/2007.

Singarimbun, M., \& S, Effendi. (1989). Metode Penelitian Survai. Jakarta:LP3ES.

Soeharjo, \& Patong,. (1973). Sendi-sendi Pokok Berusahatani. Departemen Ilmu-ilmu Sosial Ekonomi Pertanian IPB.

Soekartawi. (1989). "Prinsip Dasar Ekonomi Pertanian : Teori dan Aplikasi". Jakarta: Rajawali Pers. 
dwijenAGRO Vol. 10 No. 2, November 2020 ISSN : 1979-3901

Suratmini,N,P. 2004. pengaruh pupuk nitrogen dan pupuk kandang sapi terhadap hasil, kadar gula biji dan kadar protein kasar berangkasam jagung manis ( zea mays saaccharata sturt).(tesis). denpasar ; universitas udayana. 